\title{
African Proverbs about Women: Semantic Import and Impact in African Societies
}

\author{
Anthonia A. Dickson (Ph.D) \\ Department of Foreign Languages, University of Uyo, Uyo, Akwa Ibom State, Nigeria \\ Email: anthonia.dickson@yahoo.com
}

Mary Donald Mbosowo (Ph.D)

Department of English and Foreign Languages, Langston University, Oklahoma, U.S.A.

Email: mbosowo@hotmail.com

\section{Doi:10.5901/mjss.2014.v5n9p632}

\section{Abstract}

Proverbs are short popularly known statements which contain wisdom, truth, morals, socio-cultural precepts and heritage of a particular ethnic group. Every ethnic group in Africa and the world over has its set of proverbs, maxims and popular sayings formulated and collected over several generations. Proverbs reflect the community's world view by projecting her beliefs, moral attitudes and inner life. Existing in every language community, they constitute a very important category in African folkore. This paper examined the semantic import of African proverbs about women and their status as depicted by selected ones and wise sayings from several ethnic groups across the continent. Since the proverb is a language phenomenon and symbols in language influence thought, infact the psyche and consequently the world view, our semantic analysis of the symbols used in the proverbs will be based on the Sapir-Whorf hypothesis (Eka, 2009, p.31). Our conclusion will suggest ways by which African women will rid themselves of negative sterotypes and complexes buttressed in the culture and propagated in the use of proverbs about them.

Keywords: Proverb, Meaning, Women question, Attitudinal change.

\section{Introduction}

The Oxford Dictionary of English Proverbs (p.60) defines proverbs as a crystallized summary of popular wisdom and fancy. For Miedier, a proverb is:

A short, generally known sentence of the folk, which contains wisdom, truth, morals and traditional views in a metaphorically, fixed and memorizable form... handed down from generation to generation (Johnson and Ekpenyong, 2013, p.62).

Proverbs constitute not only a rich source of imagery but also serve as projectors of community life. They manifest socio-cultural values and heritage of the particular ethnic group. This is why Ogbalu (1956) states that:

Proverbs constitute a language of diplomacy among the lgbos... the language of settling disputes among towns... settling bride price, commerce and short oratory... Igbo proverbs are the accumulation of Igbo experience throughout the history of the Igbos (p.2).

Here Ogbalu tends to agree with Cohen's (1965) definition of proverbs "as the safest index to the inner life of a people" (p.48). Adandé adds that they are "indispensable for those who wish to understand the souls of African people" (Roscoe, 1971, p.124).

Achebe says proverbs are "the palm oil with which words are eaten" (Johnson and Ekpenyong, 2013, p.74). The universality of proverbs cannot be overstressed as each ethnic group in Africa has its set of proverbs, maxims and popular sayings formulated and collected over generations. Proverbs constitute a very important category of African oral folklore.

Hence, this paper aims at examining the semantic import of African proverbs about women and their impact on the roles and status of women, as depicted by selected proverbs and wise sayings from several ethnic groups across the continent. Because they express social and cultural precepts deeply rooted in the minds of the people, these proverbs 
yield valuable insight into the women question and the inequality in male/female relationship in the African society. The paper shall suggest ways by which African women can rid themselves of the negative stereotypes and complexes buttressed in the culture and propagated through the use of proverbs.

Efforts have been made to present most of the proverbs and sayings in their original African language with English and French translations to give the reader a full flavour of the original language. Those written in English are self explanatory.

The paper will examine the intended meaning encapsulated in the symbols, words, sentences and sentiments expressed in the proverbs. Some popular names used to refer to women in urban areas have also been included in this study.

\section{Conceptual Definitions}

Speech: Speech is a natural capability to speak. It could be compared with any natural act like walking, eating, dancing etc. It is instinctive, innate and unique to the human specie. Linguistically, speech is the consequence of the agglomeration of sounds (phonemes) that produce words (monemes) which, through syntactic processes, are combined to produce statements in a given language.

Language: Martinet (1970) defines language as an instrument of communication used for expressing and analyzing daily human experiences. Mercer and Wanderer (1971) add that it is the pivot, the factor controlling the processes by which man maintains the social group to which he owes his existence as a personality. To Sapir (in Essien, 2010, p.11), language is a pure human and non instinctive method of communicating ideas, emotions, desires by voluntarily produced symbols. This falls in line with Essien's (ibid. p.12) submission that with language "we can best... express our soul...". Summarily, language makes the human, human because it serves as the mirror of his soul.

Woman: An adult female of the human race endowed with all capabilities and talents required to function and make an impact on all levels of life within the society. She is the counterpart of a man. She is a daughter, a wife in the business of making a home, a mother - the seat of life, hence, a declaration such as "Mother is Gold"! (Roscoe, 1971).

Society: a grouping of human beings, larger than a community, containing various communities, more diffused and pluralistic in its components. It is constituted by families, villages, clans, towns, wards, local governments, governors and the governed.

Semantics: The study of meaning or sense implicated in the words and sentences of a language. Meaning changes colour like a chameleon depending on the speaker, hearer, context or setting of the words and sentences in question, Ndimele (2007).

\section{Theoretical Framework}

That language serves as a tool for thought, self expression, analysis and interpretation of experiences is what informed our choice of the Sapir-Whorf hypothesis as best suited for this type of study. The theory which, as cited in Eka (2008), expounds on the influence of language on the mind and consists of two principles, namely:

(i) Linguistic determinism which states that language influences thought.

(ii) Linguistic relativity which maintains that language influences the way one perceives and interpretes the world.

Sapir (1929) as cited in Eka (2008) states that language habits of a community predispose certain choices of interpretation. Since our study is concerned with the semantic interpretation of African proverbs about women, this communication hopes to help the reader discover the impact of the language used in African proverbs on the thinking of Africans about their women.

\section{General Proverbs about Women}

1

Jigéen xale la, danu koy wommat (Wolof)

The woman is like a child. (She must be guided at all times.)

La femme est comme un enfant, On doit la guider tout le temps.

2

Jigéen ni ween ye sëgge la xel mi sëgge (Wolof)

The mind of the woman is as twisted as her breasts.

L'esprit de la femme est aussi penché que ses seins. 
3

Avankani Vaganag anyianga imbiri we vidavi vya vagoonaa ku dave (Kimaragoli-Luhya)

The woman never thinks beyond the bed she sleeps on.

La femme ne reflechit pas au dela son lit.

4

A woman and an invalid are the same thing (Kikuyu)

La femme et l' infirme sont dans la même catégorie.

5

Words for women, action for men (Kikuyu)

La parole pour les femmes

$L$ 'action pour les hommes.

6

Awunwaàn anie inweek $k^{\prime}$ inuà (Ibibio)

Woman's strength is in her mouth

La force d' une femme est dans la bouche.

7

Clothes for women, hoes for men (Swahili)

Les habits pour les femmes (Le bavardage est pour les femmes)

Les houes pour les hommes (Le travail est pour les hommes).

\section{8}

Nwaanyi anaghi ama uru di ya bars ganye

mgbo o ghoro ajadu (Igbo)

A woman does not know the value of her husband until she becomes a widow.

On connait l'utilité des fesses quand vient le moment de s'asseoir. On recainnait la patrie au moment de la perdre (Albert Camus).

\section{9}

Awunwaàn isidoko ayôp. (Ibibio)

A woman should not climb a palm tree (for decency reasons)

La femme ne doit pas grimper sur un palmier.

10

Aiki ta, an ba mace, rikon kuya. (Hausa)

It is awful to ask a woman to guard a hyena.

C'est terrible de demander à une femme de surveiller une hyène.

These proverbs depict gender bias and discrimination prevalent in African societies. On studying the semantic traits of such lexical items as: child, twisted, never thinks, invalid, talk, clothes, does not know, etc., one observes that they all carry the nuance of negativity. Women in the proverbs are portrayed as lazy, weak, parasitic, unintelligent, caring only about their outward appearances than hard work. Hence the Ibibio proverb:

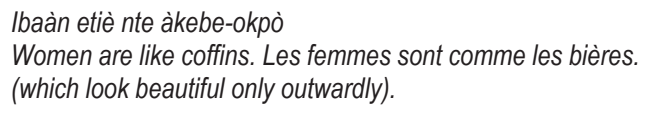

The husband is perceived more as a provider than an equal partner in a marriage setting. Reading some African novels, one notices the influence of some proverbs already cited in this study on the themes and character portraiture by the novelists. Chinua Achebe's portrayal of the female characters in Things Fall Apart (1958) and Arrow of God (1964) reflects Proverbs $2-7$. The women in these novels are portrayed as chatty, weak and incapable of thinking for themselves. They do not participate in the community governance because they are intellectually incapable of doing so. Chielo, the Priestess, talks to the men as equals only when she is in a trance during a religious ceremony.

Since the African man is seen as the sole provider in the home, he must prove himself able to care for his wife even before marriage. This leads to the issue of the bride price. Many African novelists, both male and female have written to condemn the bride price as an aspect that oppresses an African woman because it makes her a thing to be 
bought, sold, traded in or pawned for cash. The next two proverbs bear credence to this fact.

11

A woman smiles when she sees a man approaching. (Lunda) (That's because she knows that she will receive a gift from him).

La femme sourit quand elle voit un homme s'approcher d'elle.

12

Balbela ba ki bi kare, sai shanu (Hausa)

The cattle egret does not perch on a dog, it perches on a cow.

L'aigrette ne se perche pas sur un chien mais sur une vache.

That means, a woman does not fall in love with a poor man but with a rich one.

13

Jigéen soppal te bul wóolu (Woloff)

Esteem a woman but never trust her.

Estimmes la femme mais n'aies jamais confiance en elle

In Oyono's Trois Pre'tendants --- un Mari (1965) Atangana, Juliette's father wants to give her to the richest suitor, Mbia, who is already married to eight wives. The bride price system conditions the mind of most African women to seek to marry older, richer men. This system helps to perpetuate the objectization of the African woman.

\title{
5. Proverbs about Women in Polygamous Marriages
}

\author{
14 \\ Mace daya mata yaro (Hausa) \\ Marrying one wife is a young boy's thinking. \\ Avoir une seule épouse, c'est la pensée d'un garcon.
}

\section{5}

Da alheri kishiya ta hau kura (Hausa)

"Goodluck" says the co-wife when her rival climbs on a hyena.

"Bonne chance", dit la co-épouse, quand sa rivale monte une hyena

16

Kishi kumallon mata, in ya a motsa sai an haras (Hausa)

Rivalry is a woman's vomit. It can only be held down for a time. Sooner or later it pours out in the open.

La rivalité est comme le vomissement. Tôt ou tard, il se verse au grand jour.

\section{7}

Sahula, shawara da kishiya (Hausa)

It is foolish to seek advice from a co-wife.

C'est stupide de demander des conseils à une co-épouse.

18

Aure yakin mata (Hausa)

Marriage is war for women.

Le mariage, c'est la guerre pour les femmes.

Proverb (pvb) 14 indicates that the African man's social status is known by the number of wives he accumulates, afterall the woman is the "huile-calm aux flancs de l'athlète aux princes de Mali" (Senghor, 1945p.17) [calm landing-pad for the gymnastics of the princes of Mali. "Princes" represents the African men]. In pvb 16 - 18, vomit, foolish, war, occur respectively. A semantic interpretation of the three words constitute a cauldron of synonyms such as hatred, disgust, gnawing jealousy, constant battle, struggle, rancour, hostility, strife, etc. So one can see that proverbs $14-18$ contradict the notion held by many westernised Africans that our mothers and grandmothers were happy in polygamous marriages. They assert that the modern African women's condemnation of polygamy is a result of their exposure to the western culture. These few proverbs portray women suffering in silence because they have been caught in a traditional system believed to be too complicated to dismantle. Buchi Emecheta in The Joys of Motherhood (1979) and Mariama Ba in So 
Long a Letter (1981) explicate the situation of African women in polygamous marriages. The jealousy, rivalry and bad faith that is found in many polygamous homes are portrayed in these two novels. In The Joys of Motherhood, the protagonist, Nnu Ego loses her mind and dies a lonely death by the roadside after suffering for several years in a polygamous relationship. By contrast, Ramatoulage and Aissatou, the two principal characters in So Long a Letter find the strength to go on with life after their husbands decide to marry younger women. Proverb 18 summarizes most traditional African marriages as a constant war with husbands, relations and the community.

\section{Divorce in the African Society}

Divorce is a stigma in many African societies. If marriage fails, the woman is often perceived as the culprit. She is looked down upon by friends and family. Therefore, there is societal pressure on the woman to hang in there and make her marriage to succeed. An African woman does everything to avoid a marriage break down because she stands to loose many things which include children, property and prestige in her milieu.

It is necessary to state that due to the bride price system, the woman moves out of the marital home after the divorce. The husband and or his relatives keep the children. The following proverbs shed some light on the place of the woman in a traditional African setting.

19

Mata na tuba ba ta rasa jiju (Hausa)

A woman who apologises never lacks a husband.

La femme qui fait souvent ses excuses ne manqué jamais de mari.

\section{0}

Jigéen day mokk pooj (Wolof)

The woman must be docile and obedient.

La femme doit être docile et obéissante.

21(a)

Ba zangi kowaici ba, an che ba bazarawa ta hau gado. (Hausa)

A divorced woman does not refuse a man's invitation to go to bed with her.

La femme divorcée ne refuse pas de coucher avec un homme.

21(b)

Mace da ba ta yi aure ba kamar bajja ce a kasuwa, matar aure kayan mijinta ne. (Hausa)

An unmarried woman is like a cloth in the market but a married woman is the property of her husband.

La célibataire est comme un tissu au marché, mais la femme mariée est la propriété de son mari.

22(a)

Mace gona ce, ka shiga duk lokacin da ka kaso (Hausa)

A woman is like a farmland to be entered at will.

La femme est comme une ferme, n'importe qui peut y entrer à son gré.

22(b)

Woman is an ear of maize. Any man with good teeth can have a nibble at her (Beti, Cameroon)

Woman is a slender palm-tree and any man with a good belt can get up her. (Beti)

\section{3}

A chupu ajo nwaanyi n'ulo, o di ka uguru akwusiri (lgbo).

When a bad woman is driven out of the home, it seems as if harmattan has stopped.

Quand une mauvaise femme est hors de la maison, elle s'en va avec l'orage.

Proverbs 21 - 23 define the status of the single or divorced woman in the African society.

In Flora Nwapa's One is Enough (1980), the protagonist Amaka tries so hard to hold on to a childless marriage with Obiora until she discovers that he has fathered two children out of wedlock. To avoid the stigma of divorce, she moves to the capital city of Lagos to start a new life. In Emecheta's The Joys of Motherhood the married women are portrayed as individuals who are afraid to quit a bad marriage. They actually love being married and continue to hang in there even when their husband, Nnaife, can barely feed them. When Adaku, one of the wives, decides to leave the marriage, she is considered a prostitute by the community. 
Emphasis placed on marriage in African societies puts undue pressure on young women to get married. Single girls of marriageable age are looked down upon and made to feel miserable and rejected. This is because in the maledominated African societies, the woman's role is only seen within the context of the family and young unmarried women are considered prostitutes.

\title{
7. Names of Prostitutes
}

\author{
24 \\ Eni to $n$ gbele pawo (Yoruba) \\ She who earns money within the house. \\ Celle qui gagne de l'argent dans la maison. \\ 25(a) \\ Mkpo mbré okonéyò (Ibibio). \\ A night toy. \\ Un jouet pour la nuit.
}

25(b)

Aban inem. (Ibibio)

Pot containing sweetness

Un pot à sucre.

26

Money for hand, back for ground. (Nigerian Pidgin English)

Money in her hand, her back on the bed.

Aussutôt qu 'elle recoit de l'argent elle se couche sur le lit.

\section{7}

Waka-waka baby/waka about. (Nigerian Pidgin English)

One who walks about in the town.

Celle qui parcourt la ville.

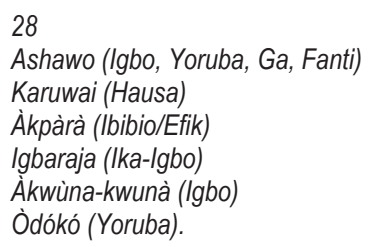

It is pertinent to note that African men do not randomly refer to women as prostitutes. This is the greatest insult a man can give to a woman which could lead to divorce, or feuds that last for several years. If and when a woman is called these names, most likely, she is actually practicing the profession. Most prostitutes move far away from their place of origin and hide out in large cities to practice their trade.

\section{Popular Sayings about Women}

\section{9(a)}

Beautiful woman no dey tey for one man house. (Nigerian Pidgin English)

A beautiful woman does not remain married for long.

Une belle femme ne reste jamais dans un seul foyer. Elle n'est jamais satisfaite d'un seul époux.

29(b)

Àdo uyaiya anwaàn akamà mkpa ìs $\wedge n$ (Ibibio)

He who marries a beautiful woman owes death a debt.

L'époux d'une belle femme doit s'attendre la mort.

30

Kadan mace ta fadi maganan biyu, ba daya vike daya (Hausa) 
If a woman speaks two words, take one word only, the other one is probably a lie.

Si la femme vous dit deux mots, prenez seulement un mot, l'autre mot est probablement un mensonge.

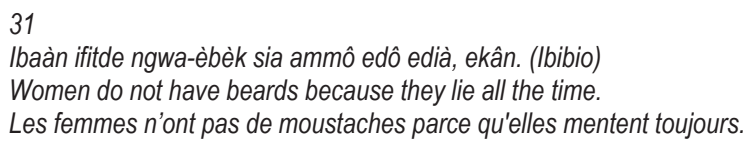

Cyprian Ekwensi and Sembene Ousmane portray proverbs 29 - 33 in their novels, Jagua Nana (1961) and Xala (1976) respectively. Jagua, Ekwensi's protagonist, abandons her husband and moves to the capital city, Lagos "to enjoy life." In Xala, Ngone quickly abandons El Hadji Abou Kader Beye once she discovers that he has "the Xala" (temporary impotence). These are beautiful women who wish to flaunt their beauty outside the confines of marriage. Consequently, they lose respect in the community.

\section{Positive Proverbs about Women}

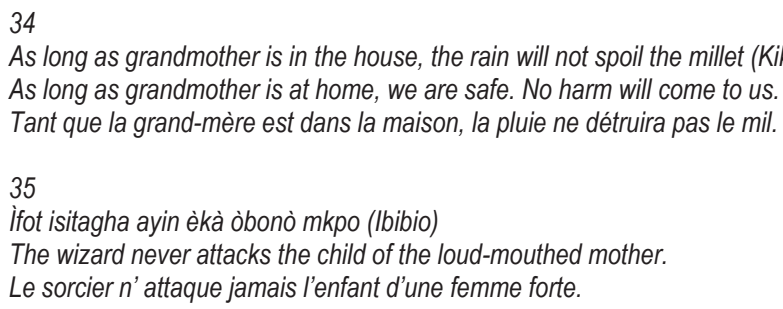

Proverbs 34 - 37 portray the high esteem African societies place on mothers. Chinua Achebe treats this aspect in Things Fall Apart. After Okonkwo, the protagonist, murders a man by accident, he chooses to make his mother's village his place of exile because as one sees in proverbs 36 and 37, only the mother can effectively wipe the tears of the child. Only the mother gives unconditional love.

\section{Names given to Professional Women}

In recent years, African women have made considerable progress both socially and educationally. Many of them have left the rural areas to settle in cities and have become economically very active. These are the "New African Women" eager to carve a niche for themselves in the male-dominated societies. However, these women have not escaped the traditional stereotypes. The following names used to refer to them portray the prevalent gender bias. 


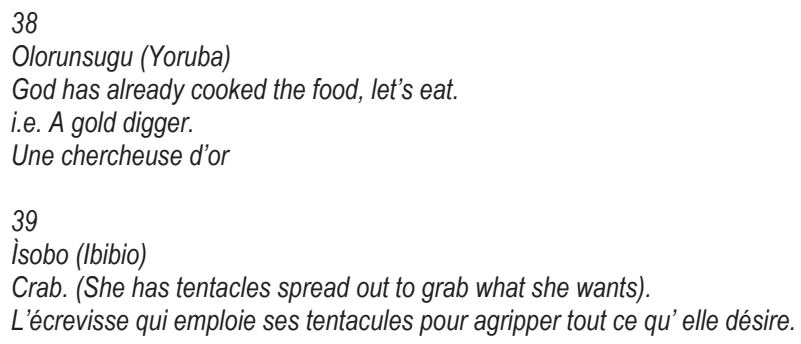

40

Oga Madam (Nigerian Pidgin English)

Boss lady.

La patronne.

41

Cash madam (Nigerian Pidgin English)

Boss lady, rich and assertive

La patronne, riche et autoritaire

42

Awunwaàn itiabà (Ibibio)

A woman who is worth seven women.

She is bold and confident of her abilities.

'Itiaba'-seven, is the complete number in Ibibio mythology.

La femme qui a la valeur de sept autres femmes. Elle travaille dur et elle a confiance en sa capacité de réussir.

43

Awunwaàn/awudeèn, (Ibibio)

A he/woman, a woman/man, hard working woman, a muscular woman.

La femme qui travaille aussi dur que l'homme.

44

Mace da kamar maza kware ne babu (Hausa)

A strong woman, but without an arrow (arrow = male sex organ)

Une femme forte mais sans fléche (le pénis)

45

Ekebò mfet k'us^n (Ibibio)

A strong willed woman whose penis was taken from her on her way to the earth.

Une femme energique dont on a oté le pénis en voie á la terre.

46

Àdàt anyèn awùnwaàn (Ibibio)

A red-eyed woman

Une femme aux yeux rouges.

Among the Ibibios, the colour "Red" is synonymous with wild, uncontrollable and domineering characteristics.

La femme qui bouscule tout le monde pour bien advancer sa carrière.

Several African writers have endeavoured to portray the "New African Women" in their novels. Flora Nwapa's Amaka in One is Enough refuses to be bogged down by stereotypes and oppressive norms. She moves away to seek for fortune in the big city: She not only becomes a "cash madam" but also fulfills her life's desire to be a mother. In Ngugi Wa Thongo's Devil on the Cross (1980), Wariinga, the protagonist, overcomes the gender discrimination and the sexual harassment that she encounters as she climbs up the career ladder. Aissatou, in So Long a Letter refuses to share her husband with another woman. She leaves him and moves on to become a bilingual secretary abroad.

If we agree with Cohen's definition (1965) of proverbs we can postulate that gender inequality and discrimination have always been a part of African culture before and after colonialism. Gender inequality is prevalent in high degree in villages and communities which have not had any direct western influence. The men control power in salient areas like 
economy, politics, family life and traditional worship ceremonies. In matrilineal societies, like the case of the Ashanti Kingdom of Ghana, where the queen mother plays a key role in choosing the next heir to the throne, economic and political power still rests in the hands of these men. For these reasons among others, we argue in this paper that the colonialists can not take all the blame for gender inequality in African society.

The proverbs examined expose the institutionalized subjugation, intimidation and oppression of African women as a result of patriarchy. Polygamy, bride system and the male child syndrome have been tools of oppression on the African woman for generations. According to Achufusi (1994)

In the Igbo world-view (and indeed in most African societies) a grown woman earns the respect of her people if she is married. She becomes fully integrated into her husband's family if she bears children. But she becomes entitled to any material inheritance only through the male children (p.105).

Most African women still see marriage and childbearing as the only source of self fulfillment. The Patriarchal system that operates in most African communities cause women to be treated as objects, chattels, property to be passed from father to husband and husband to father in case of a divorce.

\section{Validity of the Sapir-Whorf Hypothesis in the Study}

The theoretical framework for this study indicates that the language used in a given community influences the way its members analyse and interpret their daily experiences and world view. The semantic analysis of the 'signifié' (signified) encapsulated in African proverbs about women across the continent portray the negative and dehumanizing attitude of the male prevalent in African patriarchal society and the self-negating mentality developed and imbued in the female. The mind-set has been influenced and tinted by the language-use in the community. Consequently the man assumes a superiority complex which he considers his 'birthright' while the woman is cowed into subordinancy. Truly, language pervades the human essence!

\section{Conclusion}

While colonialism introduced the western form of sexism to the African society, it also, in a way enlightened the concept of inequality. Acquisition of western education provided women with tools to assess their status, change their roles and stand up against gender discrimination. The "New African women", independent and strong-willed, strive for self realization and fulfillment in all spheres of their lives and for recognition as active contributors to the developmental process of the society.

There can be no society without women because God's assignment to them is to mother the world. In the home which is the bedrock of the society, the woman is the vital key factor in the family unit. A Yoruba proverb states thus:

\section{'Okurin lori, obirin lorun' \\ Man head, woman neck \\ Homme tête, femme cou.}

It is to note that without the neck, the head would be floating in the air. Families form communities and communities form nations. Therefore to consider the woman, the seat of life, as a mere shallow-minded (cf. Prvbs $2 \& 3$ ) object "à...échanger contre quelques chameaux (which could be exchanged for camels) Farah (1987), an egg-laying machine, a farm tractor, a cook, etc, is unfair and debasing.

Education is the only panacea, the sine qua non for remoulding the psyche of African women. It is the liberating force that ensures the mobility and development of her potentials. It is pertinent to note that African women who have not even acquired western education have taken a serious look at their educated counterparts. They refuse to succumb to repressive norms and gender stereotypes. The African society is fast changing but the basic assumptions about women have been slow to change. The women have to devise a mechanism to get rid of the negative self-image brought upon them by the negative symbols immersed in statements and proverbs about them and generations of patriarchal ideology.

African women need to work harder to get elected into decision-making positions in their governments. With these positions they should be able to educate other women to reject fear, inferiority complex and other negative attitudes which portray them as naïve and unproductive. Above all, it is the onus of women to ensure a peaceful home and show good examples to the family especially to the children.

We contend in this paper that new proverbs and wise sayings need to be formulated by women to show their changing roles in society because as these new maxims take root in the society, so will the old gender stereotypes 
become obsolete and later on discarded entirely. Finally, this present generation of African women owes it to the next generation to rewrite or remove from their languages, all negative proverbs, names and popular sayings that debase women and make them second class citizens in their respective communities.

\section{Aknowledgements}

We are grateful to the following for supplying us with the proverbs used in this paper, in their native forms.

i) Dr. Mary D. Mbosowo Langston University, Langston, OK., U.S.A.

Coordinator, Study Abroad Programme, West Africa.

ii) Professor Joseph T. Uyanga Visiting Scholar, MOI University, Eldoret, Kenya

iii) Very Rev. Fr. Leo J. C. Mozie, Rector All Hallows Seminary, Onitsha, Anambra State, Nigeria

iv) Mr. \& Mrs. Moses \& Funke Olusegun, Osun State, Nigeria.

v) Mr. \& Mrs. Oludare \& Adedoja Fasugba, Osun State, Nigeria.

vi) Chief Edet George Asuquo, Akwa Ibom State, Nigeria.

\section{References}

Achebe, C. (1958). Things Fall Apart. London: Hutchinson.

Achebe, C. (1964). Arrow of God. London: Heinemann.

Achufusi, I. (1994). Feminist Inclinations of Flora Nwapa: Critical Theory. African Literature Today, 19. Trenton, New Jersey: African World Press Inc.

Ba, M. (1981). So Long a Letter. London: Heinemann, (Translated by Modupe Thomas.)

Cohen, A. (1965). Proverbs, Customs and Politics or urban Africa: A Case Study of Hausa Immigrants in Yoruba Towns. California: Berkeley Press.

Eka, D. (2008). Issues in Nigerian English Usage. Uyo: Scholars Press.

Ekwensi, C. (1961). Jagua Nana. London: Hutchinson.

Emecheta, B. (1979). The Joys of Motherhood. New York: George Brazillier.

Essien, O. (2010). Vital Aspects of Linguistics. Port Harcourt: M \& J Grand Orbit Communications Ltd.

Farah, N. (1970). Née de la Côté d'Adam. Paris: Hatier, 1987. (Translated) From a Crooked Rib. London: Heinemann.

Johnson, E. \& Ekpenyong, E. (2013). Ibom Cultural Offerings. Ghana: Univ. of Cape Coast Press.

Martinet, A. (1970). Eléments de Linguistique Générale. Paris: Armand Colin.

Mercer, B. E. \& Wanderer, J. J. (1971). The Study of Society. California: Wardsworth Publishing Company.

Ndimele, O. M. (2007). Semantics and the Frontiers of Communication. Port Harcourt: Univ. of Port Harcourt Press Ltd.

Ngugi, W. T. (1980). Devil on the Cross. London: Hutchinson.

Nwapa, F. (1980). One is Enough. Enugu: Tana.

Ogbalu, F. C. (1965). Ilu Igbo. Ibadan: Univ. of Ibadan Publishing Co.

Ousmane, S. (1976). Xala. Chicago: Lawrence Hill. (Translated by Clive Wake).

Oyono-Mbia, G. (1965). Trois Prétendants...Un Mari. Yaounde, Cameroun: Editions CLE/Presses, Pocket.

Roscoe, A. A. (1971). Mother is Gold. Cambridge: University Press.

Sani, S. M. (1990). Semantic Interpretation of Proverbs About Women: A Case Study of Toro Local Government of Bauchi State. PhD Thesis. Univ. of Jos, Nigeria.

Senghor, L. S. (1945). Chants D'Ombre. Paris: Le Seuil.

Sofola, Z. (1991). Feminism and African Womanhood in Correct Perspective, Keynote Address at the Seminar of English Literary Circle, Univ. of Jos, Nigeria.

Wilson, K. (1970). The Oxford Dictionary of English Proverbs. London: Oxford University Press. 